\title{
Size-fractionated primary production, bacterial production and net community production in subtropical and tropical domains of the oligotrophic NE Atlantic in autumn
}

\author{
Xosé Anxelu G. Morán ${ }^{1, *}$, Emilio Fernández², Valesca Pérez² \\ ${ }^{1}$ Instituto Español de Oceanografía, Centro Oceanográfico de Xixón, Camín de L'Arbeyal, s/n, 33212 Xixón, Spain \\ ${ }^{2}$ Facultad de Ciencias, Universidad de Vigo, Campus Lagoas-Marcosende, 36200 Vigo, Spain
}

\begin{abstract}
The biomass and metabolism of the planktonic microbial community was assessed at 7 stations in the eastern subtropical and tropical domains of the North Atlantic subtropical gyre in autumn 2001. Picoplankton formed the bulk of phytoplankton $(70 \pm 3 \%$ SE of total chlorophyll a), with Prochlorococcus spp. as the dominant group and an increasing importance of picoeukaryotes and Synechococcus spp. in tropical waters. Autotrophic plankton biomass clearly exceeded that of heterotrophic bacteria in the upper $150 \mathrm{~m}$, contradicting previous claims of marked inverted biomass pyramids in the oligotrophic ocean. Despite the dominance of picoplankton in biomass, primary production (range 153 to $337 \mathrm{mg} \mathrm{C} \mathrm{m}^{-2} \mathrm{~d}^{-1}$ ) was mostly due to cells $>2 \mu \mathrm{m}(59 \pm 3 \%$ ). Primary production by microphytoplankton was significantly greater in the tropical domain. Bacterial heterotrophic production (range 6 to $22 \mathrm{mg} \mathrm{C} \mathrm{m}^{-2} \mathrm{~d}^{-1}$ ) was always below $10 \%$ of primary production. This low value was probably related to the high proportion $(56 \pm 2 \%)$ of inactive bacteria (identified by their DNA content). Although bacterial activity covaried with primary productivity, bacterial carbon demand estimated by 2 models from the literature generally required organic matter input other than dissolved primary production. Given that community respiration $\left(116 \pm 32 \mathrm{mmolO}_{2} \mathrm{~m}^{-2} \mathrm{~d}^{-1}\right)$ also exceeded gross primary production $\left(58 \pm 32 \mathrm{mmolO}_{2} \mathrm{~m}^{-2} \mathrm{~d}^{-1}\right)$ at all but 1 station, our results confirm previous observations of the net heterotrophic balance in the oligotrophic NE Atlantic.
\end{abstract}

KEY WORDS: Microbial plankton - Size-structure - Primary production - Bacterial production · Community metabolism $\cdot$ Subtropical gyre $\cdot$ Atlantic Ocean

Resale or republication not permitted without written consent of the publisher

\section{INTRODUCTION}

Oligotrophic waters within the subtropical gyres comprise $\sim 70 \%$ of the world's ocean surface, and despite their lower contribution to oceanic primary production (Longhurst et al. 1995) they are key components of our understanding of marine biogeochemistry. For geographical reasons, the North Atlantic subtropical gyre has been extensively studied and its hydrographic characteristics are presently well established (e.g. Pingree 1997, 2002 and references therein, Garçon et al. 2001). Our knowledge of the metabolism of planktonic communities and their spatial and temporal scales of vari- ability is, however, still limited. The North Atlantic subtropical gyre spreads over several of the ecological provinces defined by Longhurst (1998). Most of its area corresponds to the NAST (North Atlantic Subtropical Gyral Province) and NATR (North Atlantic Tropical Gyral Province), regarded as typically representative of oligotrophic open-ocean waters. Due to the prevalence of oligotrophic conditions during most of the year, these regions are characterized by very low values of autotrophic biomass and primary production (typically below $30 \mathrm{mg}$ chlorophyll $\mathrm{a} \mathrm{m}^{-2}$ and $300 \mathrm{mg} \mathrm{C} \mathrm{m}^{-2} \mathrm{~d}^{-1}$, respectively: Marañón et al. 2000) with episodic pulses of enhanced production associated with mesoscale features 
(Fernández \& Pingree 1996, González et al. 2001, Arístegui \& Harrison 2002, Mouriño et al. 2001).

As in other open-ocean regions, phytoplanktonic biomass in the North Atlantic subtropical gyre is clearly dominated by picoplankton, as shown by studies of size-fractionated chlorophyll a (e.g. Jochem \& Zeitzschel 1993, Marañón et al. 2001) and the distribution of Prochlorococcus spp., Synechococcus spp. and picoeukaryotes (Li 1995, Partensky et al. 1996, Zubkov et al. 1998, 2000a). The recognition of the dominance of the picophytoplanktonic fraction in both biomass and activity (Platt et al. 1983, Buck et al. 1996, Marañón et al. 2001), although with significantly different proportions (Fernández et al. 2003), has boosted the investigation of the heterotrophic components of the microbial food web, such as bacterioplankton biomass and activity (Zubkov et al. 2000b, Teira et al. 2003), or protistan distribution (Quevedo et al. 2003) and grazing (Quevedo \& Anadón 2001). Presumably the predominance of microbial food web processes helps explain the relatively high values of dissolved organic carbon (DOC) production in the open ocean compared to that in coastal systems: $>20$ versus $\sim 5 \%$ of total primary production, respectively (Teira et al. 2001, Morán et al. 2002a). Recently, it has been shown that the variability in primary productivity is not reflected in significant changes in autotrophic biomass (Marañón et al. 2001), hence plankton-mediated biogeochemical fluxes in oligotrophic gyres cannot be approached by biomass assessments as in more productive systems. The available studies on the metabolic balance of planktonic as-

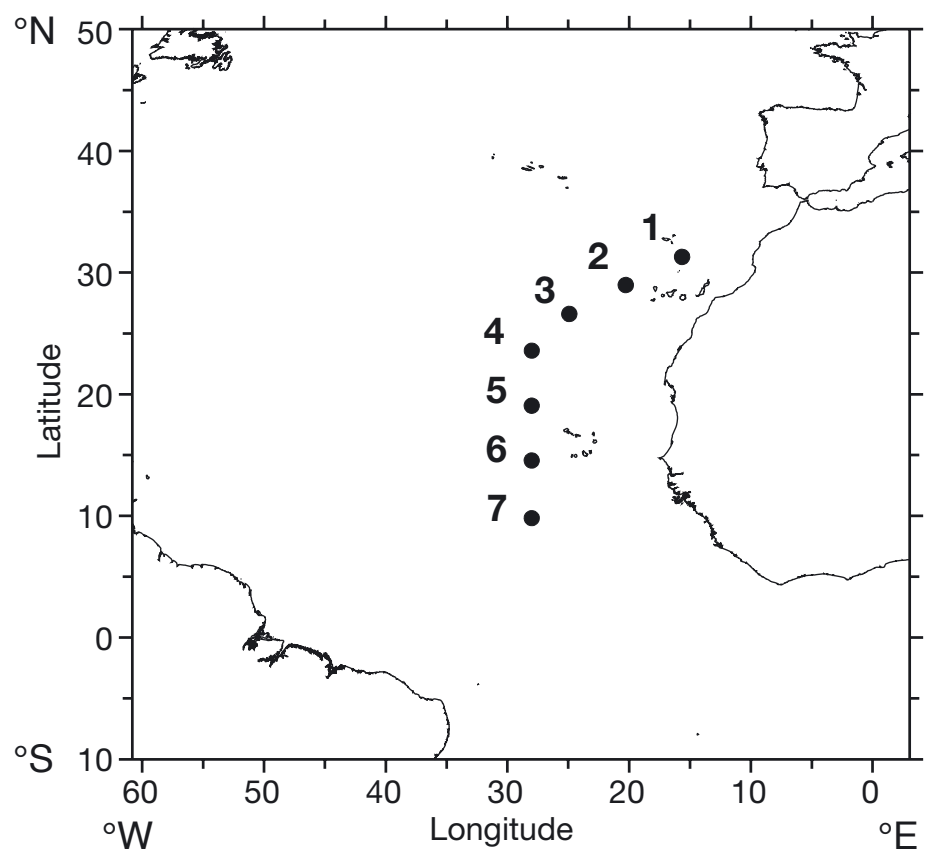

Fig. 1. Map of stations sampled semblages have consistently found that respiration exceeds primary production in the NE Atlantic (Duarte et al. 2001, González et al. 2001, 2002, Serret et al. 2001).

Despite the valuable information gathered on the above-mentioned aspects, a comprehensive study has not yet been attempted in the region that includes a description of the standing stocks of microbial plankton as well as fluxes of organic matter and their variability along the latitudinal gradient between the NAST and NATR provinces. These 2 provinces, clearly separated in the eastern part by the Subtropical Convergence (STC) or Subtropical Front (Fernández \& Pingree 1996), represent different ecological domains, with subtropical waters being comparatively more oligotrophic than the tropical waters affected by the proximity of the equatorial upwelling (Longhurst 1998).

We present here data on phytoplankton and heterotrophic bacteria distribution together with estimates of both autotrophic and heterotrophic activity (size-fractionated primary production and bacterial production), as well as gross primary production, net community production and respiration in the eastern subtropical and tropical domains of the North Atlantic gyre in autumn. In addition, bacterial carbon demand was estimated by 2 different models from the literature (del Giorgio \& Cole 1998, Rivkin \& Legendre 2001) and compared with community respiration measurements in order to gain insight into the variability of planktonic carbon balance in these regions of the oligotrophic ocean.

\section{MATERIAL AND METHODS}

Sampling site. Measurements of standing stocks and activities of the microbial communities were made at 7 stations covering a latitudinal gradient within the North Atlantic subtropical gyre (Fig. 1) during the cruise FICARAM 2/CIRCANA-I on board the RV 'Hespérides' from 29 October to 4 November 2001. At each station, the vertical distribution of temperature and salinity was obtained with a Neil Brown Mark III CTD and that of photosynthetically active irradiance (PAR, 400 to $700 \mathrm{~nm}$ ) with a Satlantic OCP-100 FF sensor. Water samples were collected with 121 Niskin bottles attached to a rosette sampler.

Size-fractionated chlorophyll a. Size-fractionated chlorophyll a (chl a) concentrations were measured for $250 \mathrm{ml}$ water samples collected from 5 to 7 depths, from the surface $(5 \mathrm{~m})$ down to $100-150 \mathrm{~m}$, after inspection of the downcast CTD fluorescence profile. Samples were filtered sequentially through 20, 2 and $0.2 \mu \mathrm{m}$ polycarbonate filters. After extraction with $90 \%$ acetone at $4^{\circ} \mathrm{C}$ overnight, chlorophyll a fluorescence was determined with a 10 SU Turner Designs fluorometer calibrated with pure chl a. 
Picoplankton abundance. The abundance of heterotrophic and phototrophic picoplankton was determined on board ship with a FACSCalibur (Becton \& Dickinson) flow cytometer. Heterotrophic bacterioplankton, Synechococcus spp. and Prochlorococcus spp. cyanobacteria, and small photosynthetic eukaryotes (picoeukaryotes) were discriminated. Samples were taken at 10 depths from the surface down to $150 \mathrm{~m}$. Phototrophic picoplankton groups were analyzed in vivo within $<1 \mathrm{~h}$ after sampling in order to avoid losses of pigments due to fixation, especially critical in the surfacemost samples (e.g. Zubkov et al. 1998). Samples for heterotrophic bacteria $(1.8 \mathrm{ml})$ were immediately fixed with $1 \%$ paraformaldehyde plus $0.05 \%$ glutaraldehyde solution, deep-frozen in liquid $\mathrm{N}_{2}$, and stored at $-70^{\circ} \mathrm{C}$ until analysis. Heterotrophic bacteria were previously stained with Syto 13 (Molecular Probes) at $2.5 \mu \mathrm{M}$. Aliquots of a solution of fluorescent $1 \mu \mathrm{m}$ latex beads (Molecular Probes) were added as an internal standard to each tube. They were calibrated daily with TruCount tubes (B\&D) of a known concentration of another type of beads. Synechococcus spp. and Prochlorococcus spp. fluorescence could be easily identified in plots of side-scatter (SSC) by FL2 (orange fluorescence) and FL3 (red fluorescence) signals. Picoeukaryotes had a higher SSC and FL3 signal than both cyanobacterial groups, and no FL2 signal. Up to 10000 events were recorded at high flow rate $\left(\sim 6 \mu \mathrm{l} \mathrm{min}{ }^{-1}\right)$ in every sample. Two groups of heterotrophic bacteria, distinguished by their relative FL1 signal (green fluorescence), were called high-(HDNA) and low-(LDNA) DNA bacteria. HDNA bacteria generally correspond to the most active fraction of the total community (Gasol et al. 1999, Lebaron et al. 2001).

Picoplankton abundance was transformed to biomass with the empirical conversion factors obtained by Zubkov et al. (1998, 2000a): 32 fg C per Prochlorococcus spp. cell, $103 \mathrm{fgC}$ per Synechococcus spp. cell, $12 \mathrm{fg} \mathrm{C}$ per heterotrophic bacterium and $1496 \mathrm{fgC} \mathrm{cell}^{-1}$ for picoeukaryotes.

Size-fractionated primary production. Sampling for size-fractionated carbon incorporation experiments was conducted between 9:30 and 11:00 h local time, except at Stn 1 (12:30 h). We filled 3 clear and 1 black acidcleaned $70 \mathrm{ml}$ polypropylene bottles with seawater collected from 5 depths chosen at fixed irradiance levels $(100,33,7,3$ and $1 \%$ of surface irradiance) within $2 \mathrm{~h}$ after sunrise. After addition of $740 \mathrm{KBq}(20 \mu \mathrm{Ci})$ of $\mathrm{NaH}^{14} \mathrm{CO}_{3}$, each bottle was incubated in an on-deck incubator refrigerated with surface seawater and provided with neutral-density screens at irradiances similar to those experienced by the cells at their original sampling depths. Incubations lasted for 6 to $7 \mathrm{~h}$, except at Stn 1 (4 h $40 \mathrm{~min}$ ). After incubation, samples were filtered at very low vacuum pressure $(<50 \mathrm{~mm} \mathrm{Hg})$ through 20, 2 and $0.2 \mu \mathrm{m}$ polycarbonate filters, which were decontaminated by exposure to concentrated $\mathrm{HCl}$ fumes for $12 \mathrm{~h}$. Filters were then placed into vials and $4 \mathrm{ml}$ of scintillation cocktail were added. Radioactivity of the samples was measured in an LKB Winspectral 1414 liquid scintillation counter. Hourly rates were converted into daily rates using the relationship between latitude and sunlight hours described by Straskraba \& Gnauck (1985). Daily rates were not corrected for phytoplankton respiration at night in order to compare ${ }^{14} \mathrm{C}$-derived primary production and $\mathrm{O}_{2}$ gross primary production.

Bacterial heterotrophic production. Bacterial heterotrophic production (BHP) was estimated at 7 depths, including those of the primary production incubactions, using the ${ }^{3} \mathrm{H}$-leucine incorporation method (Smith \& Azam 1992). We inoculated 4 replicates and 2 instantly killed controls of $1 \mathrm{ml}$ with $50 \mathrm{nmol}$ leucine in Eppendorf vials. The vials were incubated in the dark at surface temperature. Incubations lasted between 1 and $2 \mathrm{~h}$. Control and incubated samples were killed with $50 \%$ trichoroacetic acid (TCA; 5\% final concentration) and vortexed. Once killed, samples were stored at ambient temperature until centrifugation and aspiration of the supernatant. Samples were then rinsed with $1 \mathrm{ml}$ of $5 \%$ TCA and centrifugated and aspirated again; $1 \mathrm{ml}$ of scintillation cocktail was added to the vials, and the samples were counted on board in an LKB Winspectral 1414 liquid scintillation counter. Processing of samples took place on the same day as incubation. Leucine incorporation rates (pmol leu $\mathrm{l}^{-1} \mathrm{~h}^{-1}$ ) were corrected for the difference in temperature between the surface and the sampling depth with the empirically derived linear equation of Zubkov et al. (2000b). Finally, BHP was calculated from leucine incorporation rates by multiplying it by an empirical conversion factor (CF). CFs were determined during the cruise at the surface and at $150 \mathrm{~m}$ for Stns 3 and 6 , respectively, following common procedures (Kirchman \& Ducklow 1993). Since leu was mostly incorporated in the upper layers, the final value used $(0.73 \mathrm{kgC} \mathrm{mol}$ $\left.l^{-1} \mathrm{u}^{-1}\right)$ was the average of our surface value $(0.80 \mathrm{~kg})$ and 2 other surface CFs $(0.95$ and $0.46 \mathrm{~kg})$ obtained in the region during the AMT-11 cruise (A. Bode et al. unpubl. results). This CF was similar to that used by Agustí et al. (2001) in the tropical NE Atlantic (0.58). For calculating total bacterial carbon demand $(\mathrm{BCD}=\mathrm{BHP} / \mathrm{BGE})$ we used 2 estimates of bacterial growth efficiency (BGE). The first was obtained with the empirical model of del Giorgio \& Cole (1998), relating bacterial production and respiration (average BGE $2.3 \pm 0.2 \%$ for all samples), and the second was obtained with the model of Rivkin \& Legendre (2001), relating BGE and temperature (average 14.9 $\pm 4.3 \%$ for all samples). Hereafter, we refer to the $2 \mathrm{BCD}$ esti- 
mates as $\mathrm{BCD}_{\mathrm{BHP}}$ and $\mathrm{BCD}_{\text {temp, }}$ respectively. Despite their different assumptions, integrated $\mathrm{BCD}_{\mathrm{BHP}}$ and $\mathrm{BCD}_{\text {temp }}$ were strongly correlated $(\mathrm{r}=0.95, \mathrm{p}=0.001$, $\mathrm{n}=7$ ).

Gross primary production, net community production and dark community respiration. At each station, gross primary production (GPP), net community production (NCP) and dark community respiration (CR) were determined at 5 to 6 depths in the euphotic zone from in vitro changes in dissolved oxygen after light and dark bottle incubations. An additional depth was sampled for CR below the 1\% incident irradiance at the surface. Sampling and incubation were carried out at the same depths, simultaneously and under the same conditions as for $\mathrm{C}$ incorporation experiments. We carefully filled twelve $120 \mathrm{~cm}^{3}$, gravimetrically calibrated, borosilicate glass bottles from each Niskin bottle by means of a silicone tube, overflowing by $>250 \mathrm{~cm}^{-3}$. From each depth, 4 replicate bottles were fixed immediately for initial oxygen concentrations, 4 bottles were kept in darkness and 4 bottles were incubated under irradiance conditions simulating those of the original sampling depth, as described above. After the $24 \mathrm{~h}$ incubation period, dissolved oxygen concentration was determined following the recommendations of Grasshoff et al. (1983). Measurements of dissolved oxygen were made with an automated Winkler titration system performed with a Metrohm 721 Net
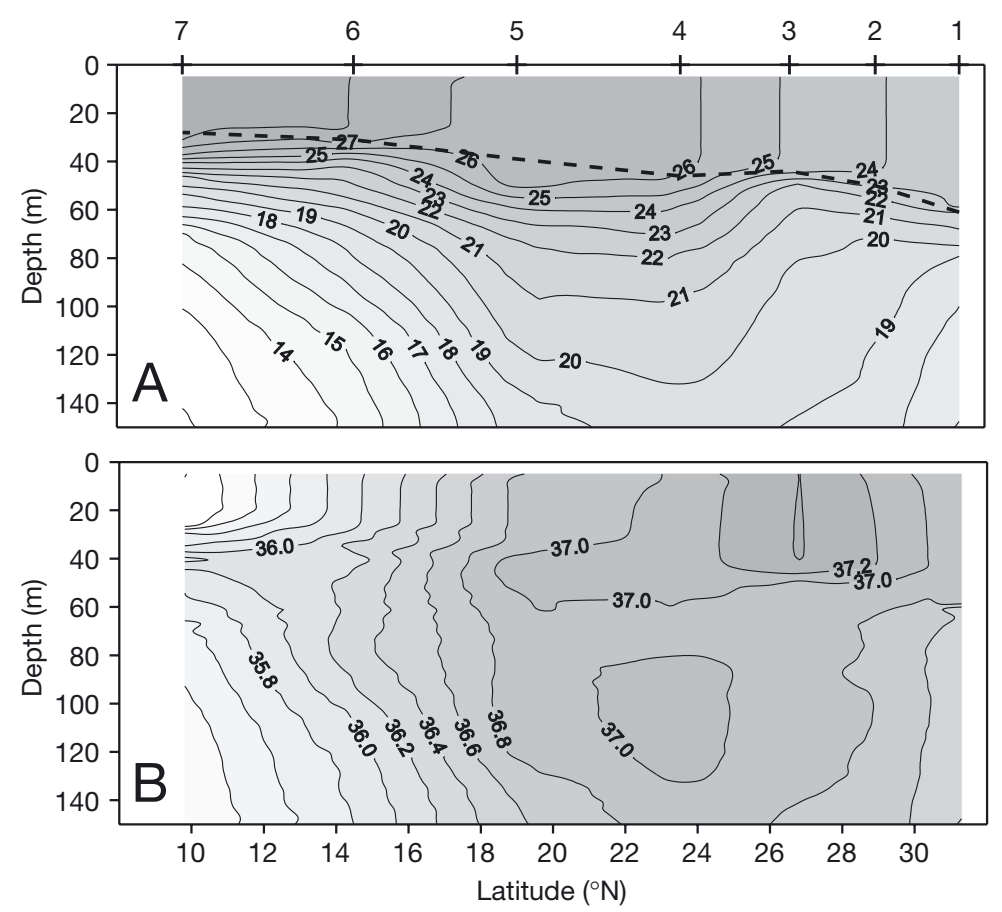

Fig. 2. Latitudinal distribution of (A) temperature $\left({ }^{\circ} \mathrm{C}\right)$ and $(\mathrm{B})$ salinity along sampled transect (Stns 1 to 7 , top abscissa). Dashed line indicates mixed-layer depth
Titrino, utilising a potentiometric end-point (Oudot et al. 1988, Pomeroy et al. 1994). Aliquots of fixed samples were delivered with a $50 \mathrm{ml}$ overflow pipette. Production and respiration rates were calculated from the difference between the averaged light and dark replicates and zero-time analyses: NCP $=$ measured $\Delta \mathrm{O}_{2}$ in light bottles (mean of $\left[\mathrm{O}_{2}\right]$ in $24 \mathrm{~h}$ light - mean initial $\left[\mathrm{O}_{2}\right]$ ); $\mathrm{CR}=$ measured $\Delta \mathrm{O}_{2}$ in dark bottles (mean initial $\left[\mathrm{O}_{2}\right]-$ mean $\left[\mathrm{O}_{2}\right]$ in $24 \mathrm{~h}$ dark); GPP $=\mathrm{NCP}+\mathrm{CR}$. During the cruise, the average coefficient of variation of the $\mathrm{O}_{2}$ concentration measurements in the initial, dark and light bottles was $0.16 \%$, and the mean of the standard errors of the NCP and CR rate measurements were $0.28(\mathrm{n}=20)$ and $0.30(\mathrm{n}=33) \mathrm{mmolO}_{2} \mathrm{~m}^{-3} \mathrm{~d}^{-1}$, respectively.

Photic zone integration. Photic layer-integrated values of GPP, CR and NCP and other variables were obtained by trapezoidal integration of the volumetric data down to the depth of $1 \%$ surface incident irradiance.

\section{RESULTS}

The thermohaline structure of the upper water column showed the existence of a distinct vertical stratification and displayed a marked latitudinal trend, with a shoaling of the mixed layer depth from subtropical to tropical waters (Fig. 2). The boundary between NAST and NATR is usually defined at 25 to $30^{\circ} \mathrm{N}$, but its exact location varies locally (Longhurst 1998). During this cruise, a clear thermohaline front separating NAST-E and NATR waters of the North Atlantic subtropical gyre was found at approximately 17 to $19^{\circ} \mathrm{N}$. According both to the vertical profiles of temperature (Fig. 2A) and their latitudinal position in Longhurst's (1998) provinces partition, Stns 1 to 4 were grouped as 'subtropical', whereas the remaining stations (5 to 7 ) along the $28^{\circ} \mathrm{W}$ meridian were grouped as 'tropical'. We will hereinafter use the terms subtropical and tropical domains as equivalent to NAST-E and NATR waters, respectively. The photic layer depth (Fig. 3A) tended to decrease from subtropical $(106 \pm 10 \mathrm{~m})$ to tropical $(69 \pm 9 \mathrm{~m})$ waters.

\section{Chlorophyll a}

Chlorophyll a (chl a) concentration ranged from 0.03 to $0.79 \mathrm{mg} \mathrm{m}^{-3}$ for all stations and tended to be higher in the tropical domain (Fig. 3A). Photic layer-integrated chl a tended to be slightly higher in the subtropical domain (Table 1), with average photic layer concentrations of $0.24 \pm 0.04$ (SE) in the subtropical and $0.30 \pm 0.05 \mathrm{mg} \mathrm{m}^{-3}$ in the trop- 

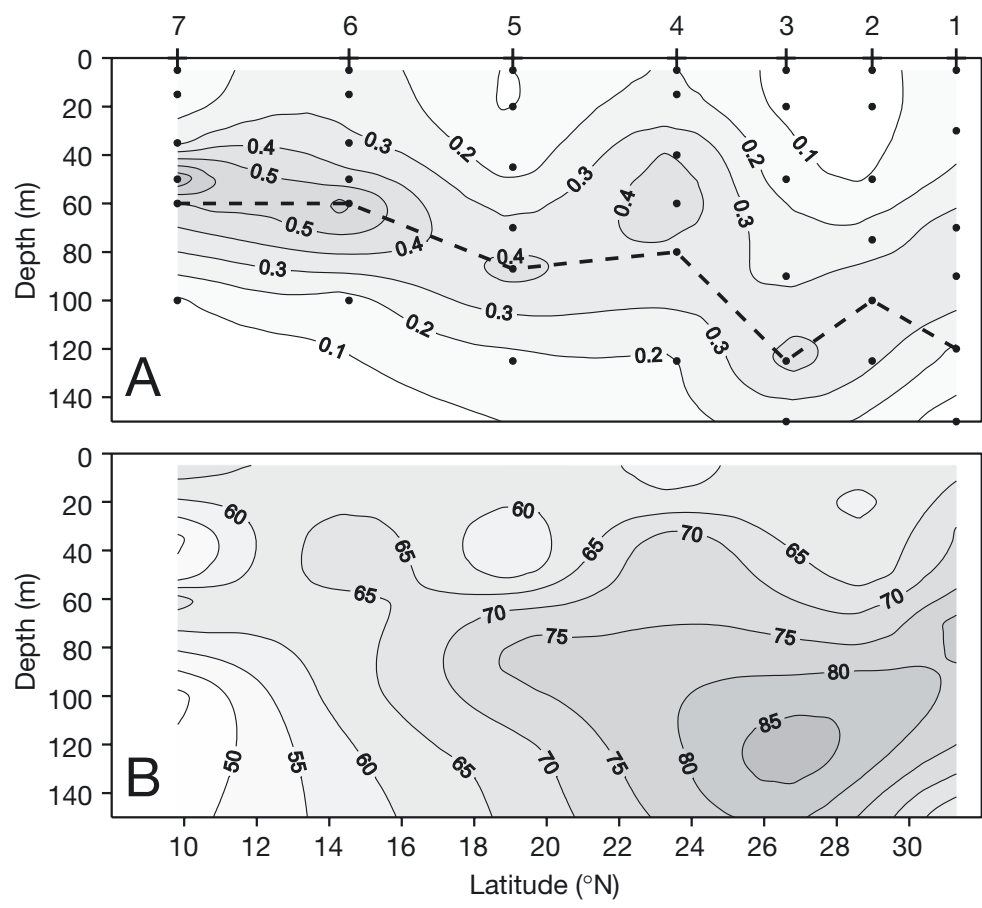

Fig. 3. Latitudinal distribution of (A) total chlorophyll a $\left(\mathrm{mg} \mathrm{C} \mathrm{m}^{-3}\right)$, and (B) percentage of chlorophyll $a<2 \mu \mathrm{m}$. In (A), dashed line indi-

cates photic layer depth and dots represent sampling depths

Table 1. Mean $( \pm \mathrm{SE})$ biomass and carbon fluxes in subtropi$\mathrm{cal}$ and tropical domains. Integrated photic layer values in $\mathrm{mg}$ chlorophyll $a \mathrm{~m}^{-2}\left(\mathrm{~d}^{-1}\right)$ or $\mathrm{mg} \mathrm{C} \mathrm{m} \mathrm{m}^{-2}\left(\mathrm{~d}^{-1}\right)$. Also shown are percentages of pico-, nano- and microplanktonic chlorophyll $a$ and primary production. ${ }^{*}$ Significant difference at $\mathrm{p}<0.05$ ( $t$-test) HDNA: high-DNA bacteria; BGE: bacterial growth efficiency. See 'Results' for details

\begin{tabular}{|lcc|}
\hline & Subtropical & Tropical \\
\hline Total chlorophyll $a$ & $25 \pm 3$ & $20 \pm 1$ \\
$<2 \mu \mathrm{m}$ & $75 \pm 2 \%$ & $63 \pm 4 \%^{*}$ \\
$2-20 \mu \mathrm{m}$ & $22 \pm 2 \%$ & $30 \pm 5 \%$ \\
$>20 \mu \mathrm{m}$ & $3 \pm 0 \%$ & $8 \pm 2 \%$ \\
Prochlorococcus spp. & $747 \pm 63$ & $615 \pm 121$ \\
Synechococcus spp. & $36 \pm 2$ & $120 \pm 47$ \\
Picoeukaryotes & $304 \pm 36$ & $519 \pm 238$ \\
Total particulate primary production & $217 \pm 41$ & $234 \pm 20$ \\
$<2 \mu \mathrm{m}$ & $43 \pm 5 \%$ & $37 \pm 4 \%$ \\
$2-20 \mu \mathrm{m}$ & $48 \pm 4 \%$ & $36 \pm 7 \%$ \\
$>20 \mu \mathrm{m}$ & $9 \pm 1 \%$ & $27 \pm 7 \% *$ \\
Heterotrophic bacteria & $891 \pm 117$ & $945 \pm 164$ \\
Percent HDNA bacteria & $44 \pm 2 \%$ & $45 \pm 3 \%$ \\
Bacterial production & $13 \pm 4$ & $15 \pm 1$ \\
Bacterial carbon demand & & \\
BCD BHP (BGE $\approx 2 \%$ ) & $568 \pm 136$ & $625 \pm 44$ \\
BCD temp (BGE $\approx 13 \%)$ & $100 \pm 34$ & $132 \pm 9$ \\
Gross primary production & $685 \pm 223$ & $716 \pm 275$ \\
Net community production & $-424 \pm 328$ & $-820 \pm 193$ \\
Community respiration & $1245 \pm 309$ & $1536 \pm 85$ \\
\hline
\end{tabular}

ical domains. The average photic layer chl a was strongly correlated with surface concentrations $(\mathrm{r}=0.93, \mathrm{p}=0.002, \mathrm{n}=7)$. Chl a was very low in the upper $40 \mathrm{~m}$ of the water column and displayed a typical subsurface maxima (deep chlorophyll maximum, DCM) with values $>0.30 \mathrm{mg} \mathrm{m}^{-3}$. The DCM became shallower and reached higher values at the lower-latitude stations (Fig. 3A).

Most of the chl a was present in small $(<2 \mu \mathrm{m})$ cells, especially in the deeper samples of subtropical waters, where picoplanktonic chl a contributed $>75 \%$ to total values (Fig. 3B). Photic layer-averaged values of this percentage were higher in the subtropical domain (Table 1, $t$-test, $\mathrm{p}=0.03, \mathrm{n}=7$ ) and displayed a consistent latitudinal pattern from $55 \%$ at Stn 7 to $77 \%$ at Stn 1. The contribution of microphytoplankton (>20 $\mu \mathrm{m})$ to total chl a was below $6 \%$ at all stations except at Stn 6, where it reached $11 \%$.

\section{Autotrophic picoplankton}

Prochlorococcus spp. was the most abundant autotrophic picoplankter at all stations, with 0 to $150 \mathrm{~m}$ weighted means of $1.75 \pm 0.10$ and $1.51 \pm$ $0.31 \times 10^{5}$ cells $\mathrm{ml}^{-1}$ for the subtropical and tropical domains, respectively. The mean abundance of the other 2 groups was 2 orders of magnitude lower. The concentration of Synechoccocus spp. and picoeukaryotes was similar in the subtropical domain $(2.46 \pm 0.18$ and $1.68 \pm 0.09 \times 10^{3}$ cells ml $^{-1}$, respectively), but Synechococcus spp. was more than double the abundance of picoeukaryotes in tropical waters $(8.19 \pm 3.06$ and $3.79 \pm 0.98 \times 10^{3}{\text { cells } \mathrm{ml}^{-1}}$, respectively). Only the abundance of picoeukaryotes was significantly different in both domains ( $t$-test for station means, $\mathrm{p}=0.01, \mathrm{n}=7$ ).

The distribution of picophytoplankton biomass along the sampled transect is shown in Fig. 4. Maximum biomass values for all groups were shallower at the lowerlatitude stations, in accordance with the chl a distribution (Fig. 3A). Picoeukaryotes generally occupied deeper layers than the other 2 groups, especially in tropical waters. The dominant group in the photic layer was always Prochlorococcus spp., but with different proportions in subtropical (69\%) and tropical (52\%) waters. The relative contributions of these 2 groups were significantly different for both domains ( $t$-tests for station means, $\mathrm{p}=0.04, \mathrm{n}=7$ ). Synechococcus spp. contributed a much lower percentage of total autotrophic picoplankton biomass, $3 \%$ in subtropical and $10 \%$ in tropical waters. Latitudinal trends were consistent for the relative contributions of the 3 groups in the upper $150 \mathrm{~m}$, with Synechococcus spp. and pico- 
eukaryotes increasing southwards $(r=-0.83$ and $\mathrm{r}=-0.89$, respectively) while the opposite was true for Prochlorococcus spp. ( $\mathrm{r}=0.88$, all $\mathrm{p}<0.02, \mathrm{n}=7$ ).

\section{Size-fractionated primary production}

Particulate primary production (PPP) was very low (Fig. 5A), in accordance with the low chl a concentrations measured in the region. Total PPP seemed to be mainly determined by the extant algal biomass, since photic layer-averaged values of both variables were significantly correlated $(\mathrm{r}=0.87 ; \mathrm{p}=0.01, \mathrm{n}=7$ ). The linear regression yielded a mean photic layer assimilation number of $0.91 \pm 0.09(\mathrm{SE}) \mathrm{mgC} \mathrm{mgchl} \mathrm{a}^{-1} \mathrm{~h}^{-1}$ similar to previous reports (Marañón \& Holligan 1999, Marañón et al. 2000), even when surface waters only were considered (Jochem \& Zeitzschel 1993). Volumet-
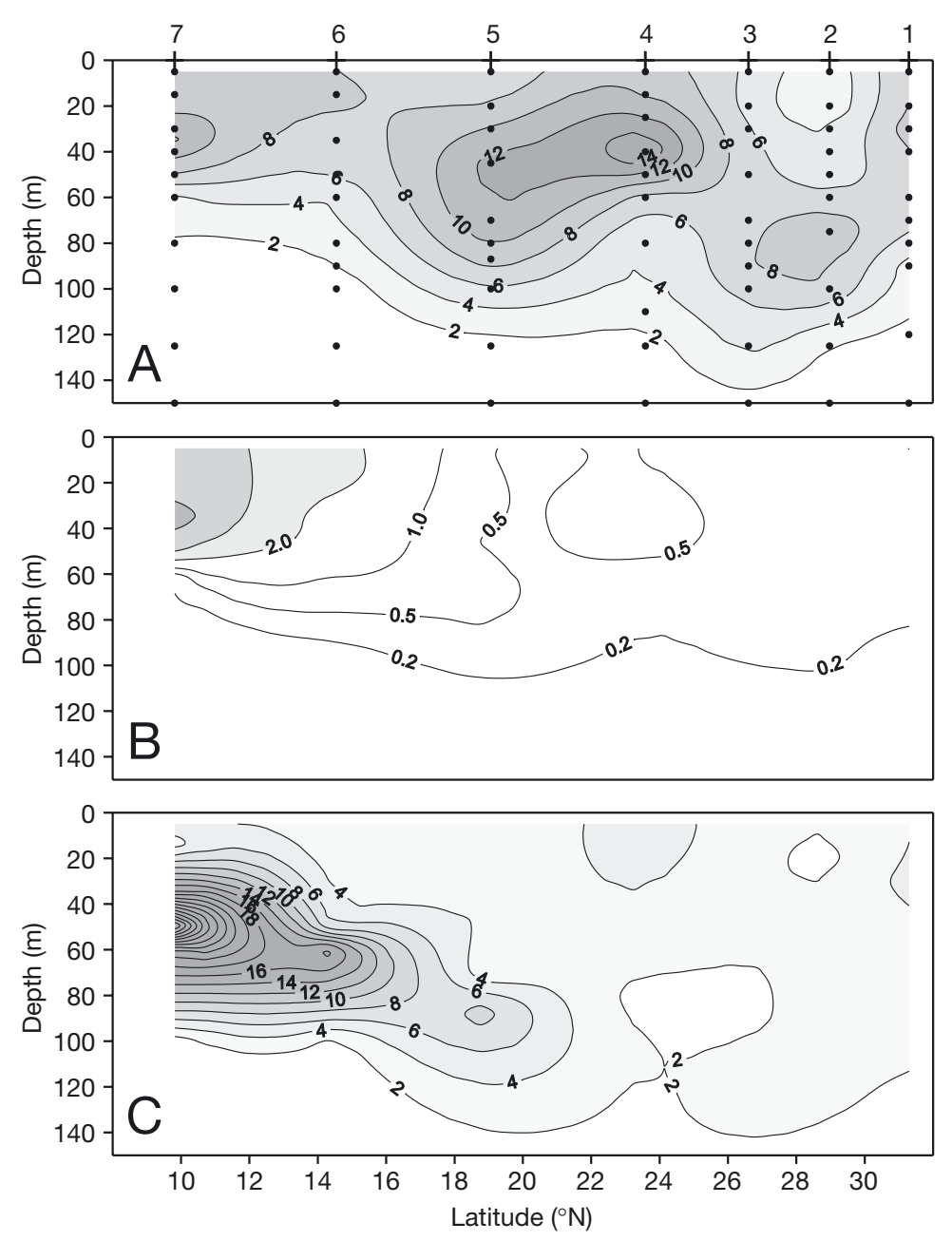

Fig. 4. Latitudinal distribution of biomass of autotrophic picoplankton $\left(\mathrm{mg} \mathrm{C} \mathrm{m}^{-3}\right)$. (A) Prochlorococcus spp., (B) Synechococcus spp.,

(C) picoeukaryotes. Dots in (A) represent sampling depths ric rates ranged from 0.02 to $0.74 \mathrm{mgC} \mathrm{m}^{-3} \mathrm{~h}^{-1}$, with generally higher values close to the surface. Highest values tended to be found in the tropical domain (Fig. 5A), with a mean photic layer value of $0.31 \mathrm{mg} \mathrm{C}$ $\mathrm{m}^{-3} \mathrm{~h}^{-1}$ compared to 0.20 in the subtropical domain. However, integrated values were not significantly different ( 200 $\mathrm{mgC} \mathrm{m}^{-2} \mathrm{~d}^{-1}$ : Table 1).

Volumetric PPP was positively correlated with the concentration of chl a $>20 \mu \mathrm{m}$, and the percentage of chl $a>2 \mu \mathrm{m}(\mathrm{r}=0.59$ and 0.56 , respectively, $\mathrm{p}<0.001$, $\mathrm{n}=35$ ), suggesting a greater effect of big cells on total rates. A consistently increasing pattern with increasing depth was evidenced in the contribution of picoplankton to total photosynthetic carbon incorporation rates. The contribution of $>2 \mu \mathrm{m}$ cells to total primary production exceeded that of picoplankton in the upper 40 to $80 \mathrm{~m}$ of both oceanic domains (Fig. 5B). Latitudinal differences in the proportion of PPP due to the 3 sizeclasses considered were less obvious than in the case of chl $a$, with no significant changes with decreasing latitude. The percentage of picoplanktonic primary production was not significantly different in the 2 regions (Table 1$)$. However, microphytoplankton $(>20 \mu \mathrm{m})$ production was significantly higher ( $t$-test for integrated values, $\mathrm{p}=0.04, \mathrm{n}=7)$ in the tropical domain (64 \pm 18 versus $19 \pm 5 \mathrm{mg} \mathrm{C} \mathrm{m}^{-2} \mathrm{~d}^{-1}$ ), where it made a significantly 3 -fold greater contribution to total rates (Table 1 ; $t$-test, $\mathrm{p}=0.03, \mathrm{n}=7$ ).

\section{Bacterial abundance and production}

Heterotrophic bacteria numbers in the upper $150 \mathrm{~m}$ of the water column were similar for both domains $\left(6.04 \pm 0.8010^{5}\right.$ cells $\mathrm{ml}^{-1}$ in subtropical and $7.87 \pm 1.0810^{5}$ cells $\mathrm{ml}^{-1}$ in tropical waters). The higher bacterial abundance in the photic layer in tropical waters $\left(1.19 \pm 0.02 \times 10^{6}\right.$ versus $7.25 \pm 1.20 \times 10^{5}$ cells $\mathrm{ml}^{-1}$ ) was due to the lower depth of the photic layer and the higher abundance in surface waters. Bacterial biomass ranged from 2 to $19 \mathrm{mg} \mathrm{C} \mathrm{m}^{-3}$, with higher values in the surface layers. Values were higher and showed subsurface maxima at the lower-latitude stations (Fig. 6A). Photic layer-integrated bacterial biomass was close to $1000 \mathrm{mg} \mathrm{C} \mathrm{m}^{-2}$ (Table 1). With all volumetric data pooled, the abundance of heterotrophic bacteria was correlated with that of the autotrophic picoplanktonic groups, but especially to Prochlorococcus spp. $(\mathrm{r}=0.62, \mathrm{p}<0.001, \mathrm{n}=70)$

Heterotrophic bacteria tended to make the major contribution to total (autotrophic and heterotrophic) picoplankton carbon in the upper $20 \mathrm{~m}$ of the water column and below $80 \mathrm{~m}$ depth. 

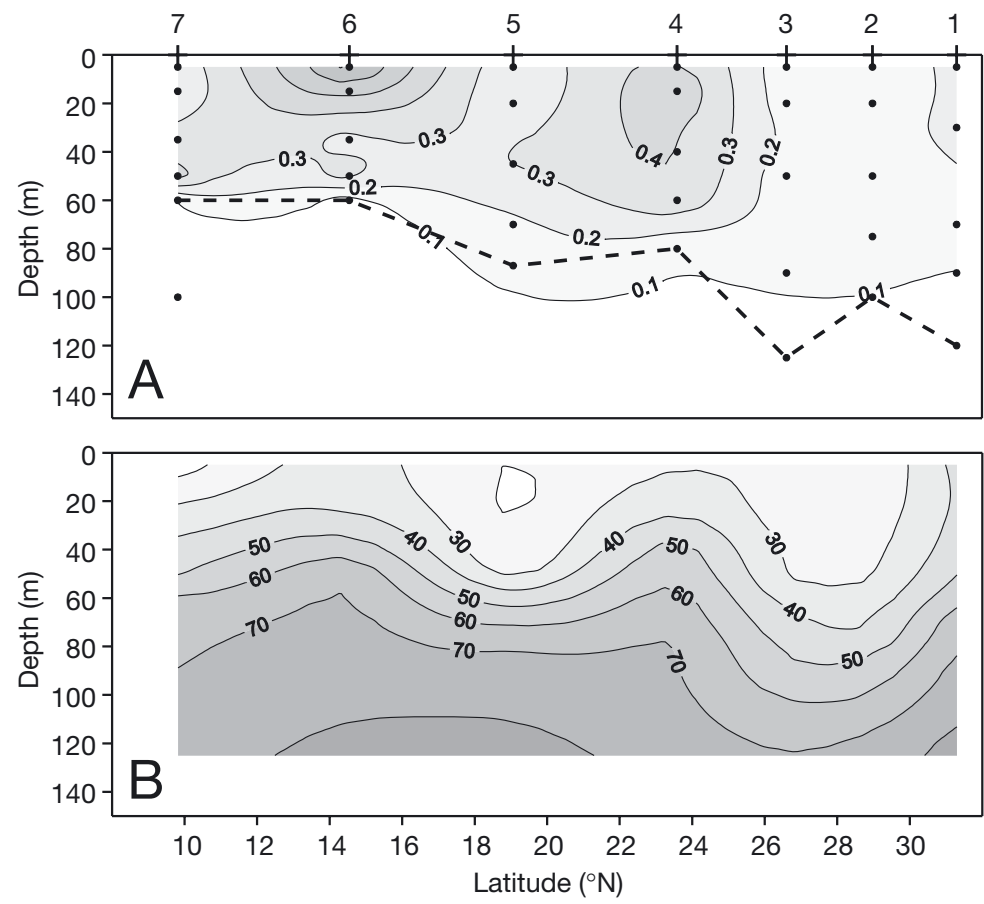

Fig. 5. Latitudinal distribution of (A) total primary production (mg C $\mathrm{m}^{-3} \mathrm{~h}^{-1}$ ), and (B) percentage of primary production by cells $<2 \mu \mathrm{m}$. In (A), dashed line indicates photic layer depth and dots represent sampling depths estimated with the bacterial production model $\left(\mathrm{BCD}_{\mathrm{BHP}}\right.$, del Giorgio \& Cole 1998) (range 273 to $905 \mathrm{mg} \mathrm{C} \mathrm{m}^{-2} \mathrm{~d}^{-1}$ ) due to the difference in the bacterial growth efficiencies (BGE) obtained with the 2 models (photic layer averages of 2 and $13 \%$, respectively). BGEs higher than $15 \%$ are usually not found in oligotrophic systems (del Giorgio \& Cole 1998, 2000). The mean BGE predicted by the photic layer-integrated bacterial and primary production rates in our experiments using the steadystate model of Anderson \& Ducklow (2001) was $12.2 \pm 0.9 \%$. Hence, we feel confident that both BCD estimates probably constrained the total flux of organic carbon through heterotrophic bacteria.

\section{Gross primary production, net community production and respiration}

The volumetric rates of gross primary production (GPP), net community production (NCP) and community respiration (CR) are shown in Fig. 7. Except in subsurface waters of Stns 4 and 6, CR exceeded GPP at all sampling depths, thus yielding negative NCP values in most of the photic layer. No clear latitudinal trends were observed for any of these variables. There was no significant
However, when the upper $150 \mathrm{~m}$ were considered, the biomass of autotrophic organisms (detected by flow cytometry) clearly exceeded that of heterotrophic bacteria, making up $72 \pm 4$ and $74 \pm 3 \%$ of picoplankton carbon in the subtropical and tropical domains, respectively.

The percentage of HDNA bacteria was generally below $50 \%$ (overall range 30 to $58 \%$ ) at most stations and depths (see averages in Table 1), and peaked in subsurface waters (20 to $50 \mathrm{~m}$ ), indicating that most bacteria were inactive (Gasol et al. 1999, Lebaron et al. 2001). Concurrent with this observation, the estimates of bacterial production rates were low (range 0.05 to $29 \times 10^{-3} \mathrm{mg} \mathrm{C} \mathrm{m}^{-3}$ $\mathrm{h}^{-1}$ ), and tended to peak at a shallower depth than biomass (Fig. 6B). The slope of the log-log regression of BB and BHP $(0.20, r=0.51, \mathrm{p}<0.001, \mathrm{n}=45)$ suggested an absent or very weak bottom-up control of bacterial biomass (Ducklow 1992). Highest values of BHP were found at Stn 4. Integrated values were 1 order of magnitude lower than primary production rates and similar for both regions (13 to $15 \mathrm{mg} \mathrm{C} \mathrm{m}^{-3} \mathrm{~d}^{-1}$ : Table 1).

The total carbon demand of bacteria estimated with the temperature-dependent model $\left(\mathrm{BCD}_{\text {temp }}\right.$, Rivkin \& Legendre 2001) was on average 5-fold lower (range 37 to $196 \mathrm{mg} \mathrm{C} \mathrm{m}^{-2} \mathrm{~d}^{-1}$ ) than when
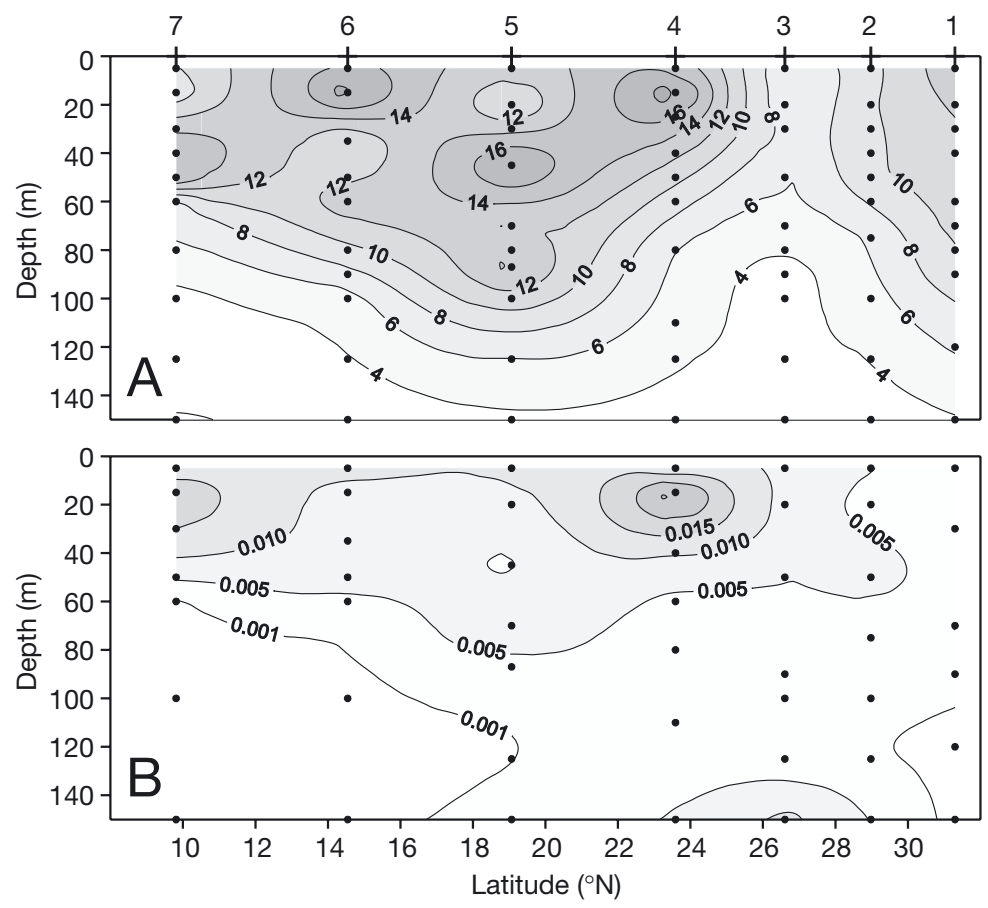

Fig. 6. Latitudinal distribution of (A) heterotrophic bacteria biomass $\left(\mathrm{mg} \mathrm{C} \mathrm{m}^{-3}\right)$, and (B) bacterial production $\left(\mathrm{mgC} \mathrm{m}^{-3} \mathrm{~h}^{-1}\right)$. Dots represent sampling depths 
relationship between GPP and CR for all data pooled, with CR being generally less variable than GPP (CR varied by a factor of 12 compared to 31 for GPP).

Integrated values of GPP ranged from 15 to $99 \mathrm{mmolO}_{2} \mathrm{~m}^{-2} \mathrm{~d}^{-1}$, with similar values in both domains, as for $\mathrm{CR}$ (range 69 to $154 \mathrm{mmolO}_{2} \mathrm{~m}^{-2} \mathrm{~d}^{-1}$ ) (see Table 1 for carbon units). CR was negatively correlated with total $\mathrm{chl} a(\mathrm{r}=-0.98, \mathrm{p}<0.001, \mathrm{n}=6)$. NCP values were negative at all stations except at Stn 4 $\left(17.2 \mathrm{mmolO}_{2} \mathrm{~m}^{-2} \mathrm{~d}^{-1}\right)$, and bore no significant relationship to any other variables.

\section{DISCUSSION}

The results presented in this paper allow further insight into the structure and functioning of the microbial food web in oligotrophic North Atlantic waters.
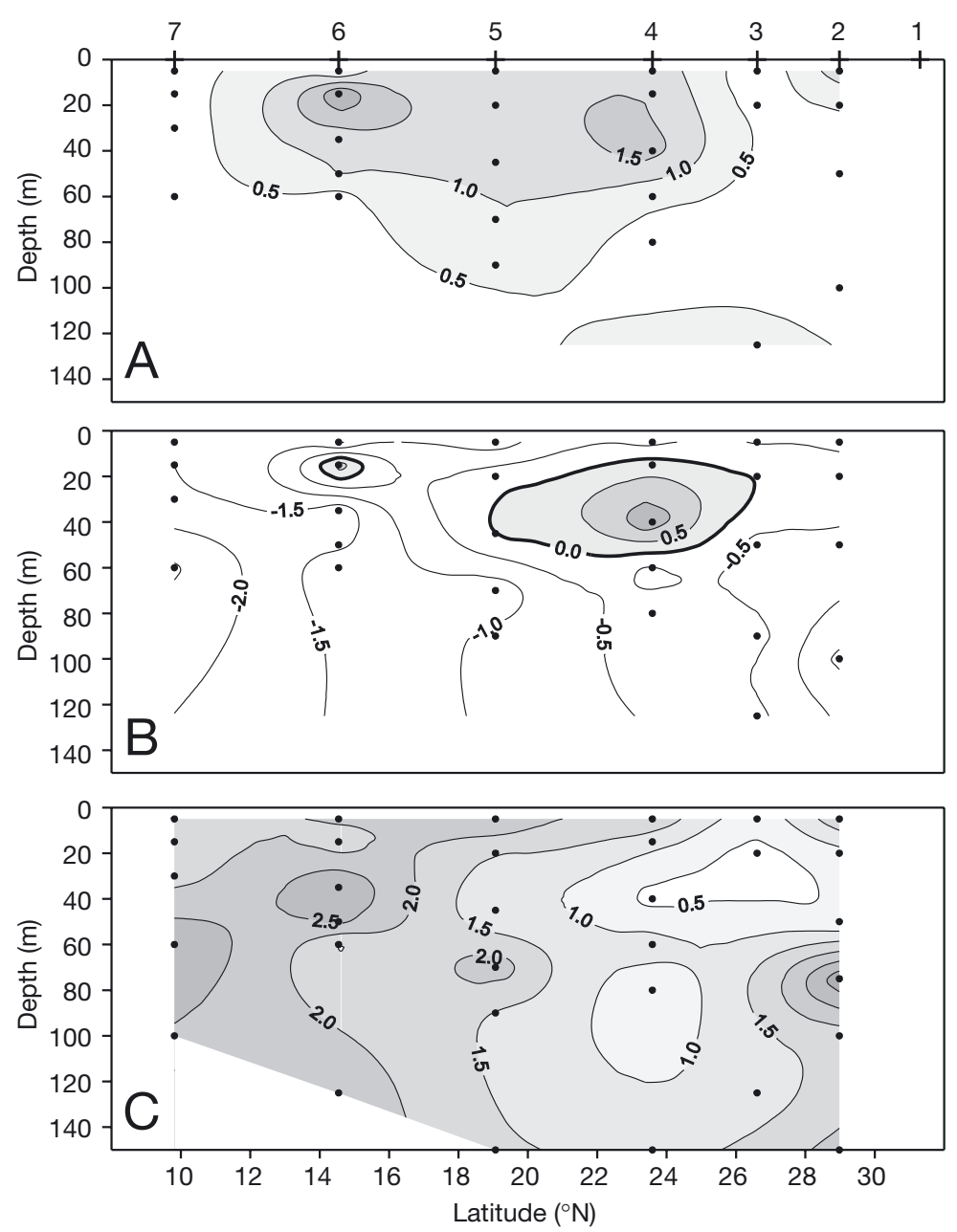

Fig. 7. Latitudinal distribution of (A) gross primary production, (B) net community production, and (C) community respiration. Units in

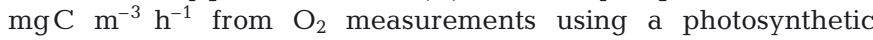
quotient and respiratory quotient of 1.0. Dots represent sampling depths
Previous surveys in the gyre (e.g. the AMT programme [Aiken \& Bale 2000] or the Spanish 'Latitude' cruises [Agustí et al. 2001]) were usually conducted further east in the gyre $\left(<22^{\circ} \mathrm{W}\right)$ than ours $\left(28^{\circ} \mathrm{W}\right)$, thus being affected to a larger extent by the African upwelling (see for instance Fig. 1 in Serret et al. 2001).

The distribution of autotrophic picoplankton was similar to that reported in previous works (Li 1995, Partensky et al. 1996, Zubkov et al. 1998, 2000a, Li \& Harrison 2001) although higher concentrations of Prochlorococcus spp., frequently exceeding $2 \times 10^{5}$ cells $\mathrm{ml}^{-1}$, were found in this survey. The maximum abundance observed $\left(5.1 \times 10^{5}\right.$ cells ml ${ }^{-1}$ at Stn $4,40 \mathrm{~m}$, Fig. 4A) is to our knowledge the highest ever recorded (cf. Partensky et al. 1999).

The low chl a fluorescence of surface Prochlorococcus spp. in oligotrophic areas may lead to abundance underestimates, especially in fixed samples (e.g. Partensky et al. 1996, Zubkov et al. 1998). This problem can be partly circumvented by analyzing populations in vivo, as we did here. The vertical distribution of Prochlorococcus spp. did not show any evidence of overlapping of the 2 subpopulations found in open-ocean Atlantic waters by Zubkov et al. (1998). Rather, we observed a steep increase in the average cell fluorescence and size at the level of the thermocline for the 3 picophytoplankton groups (data not shown).

A distinct latitudinal gradient was observed in the depth of maximum biomass and the relative contribution of the 3 picoalgal groups (Fig. 4). Whereas Prochlorococcus spp. were by far the most important picophytoplankters at the subtropical stations, picoeukaryotes exceeded prochlorophytes at the end of the transect. Changes in the relative contribution of the different picophytoplankton groups with much smaller or no changes in total standing stocks have also been reported in response to different hydrographic conditions at oligotrophic sites (Campbell et al. 1997, Gin et al. 1999, Marañón et al. 2003). No data on nutrient concentrations are available for the cruise, but the pycnocline and nutricline depths usually correspond in the North Atlantic gyre (e.g. Harrison et al. 2001), so the observed changes in picoalgal distributions were probably related to changes in nutrient availability in the upper layers.

Assuming a C:chl a ratio of 40 ( $\mathrm{Li}$ et al.1993), the picophytoplanktonic fraction alone would almost be double the total phytoplankton biomass (ratio 1.98). In order to clarify this inconsistency, we also used the empirical relationship between phytoplankton $\mathrm{C}$ and chl $a$ derived by Marañón et al. (2000) for an Atlantic meridional transect, which still yielded an estimated picoplanktonic 


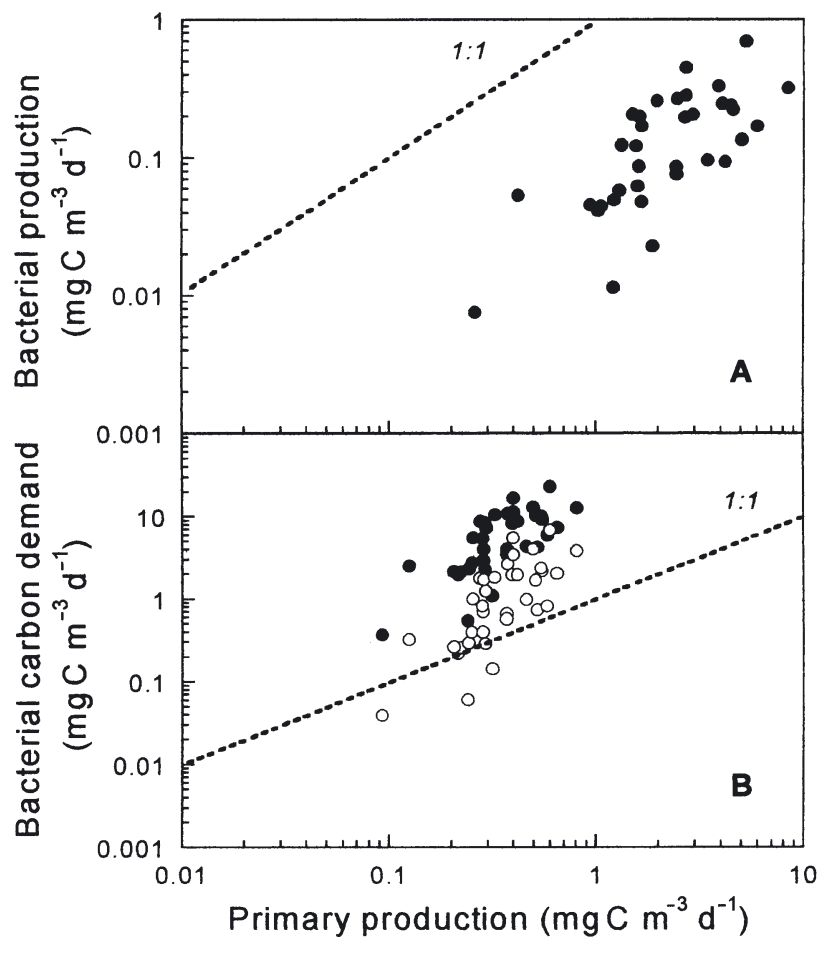

Fig. 8. Relationship between (A) bacterial (BHP) and particulate primary production (PPP), and (B) bacterial carbon demand $\left(\mathrm{BCD}_{\mathrm{BHP}}, \bullet\right.$; $\left.\mathrm{BCD}_{\text {temp, }} \mathrm{O}\right)$ and dissolved primary production $\left(\mathrm{DPP}_{3}\right)$. Notice different scales of $y$-axes. (See 'Discussion' for details)

contribution of $105 \pm 13 \%$ to total autotrophic carbon. Although some of the cells called 'picoeukaryotes' may in fact have been larger than $2 \mu \mathrm{m}$, these calculations indicate that autotrophic picoplankton comprised the bulk of the phytoplankton biomass (Agustí et al. 2001, Li \& Harrison 2001) confirming their high contribution to total chl a (Fig. 3), and that virtually no phytoplanktonic cell escaped detection by flow cytometry (as noted by Li [2002] in his analysis of open-ocean Atlantic waters).

Autotrophic phytoplankton exceeded the biomass of heterotrophic bacteria in the photic layer of all stations, in agreement with Li \& Harrison's (2001) results obtained further north in the gyre. Taking only picoplankton into consideration, the biomass of Synechococcus spp., Prochlorococcus spp. and picoeukaryotes in the photic layer was on average $35 \%$ higher than that of heterotrophic bacteria. This also applied to the upper $150 \mathrm{~m}$ ( $22 \%$ more picoalgae than bacteria). More accurate determinations of the abundance and carbon content of the different microbial groups (i.e. $12 \mathrm{fg} C$ bacteria $^{-1}$ [Zubkov et al. 2000a] rather than 20 [Lee \& Fuhrman 1987] in oceanic waters) hence do not support earlier reports of bacteria:phytoplankton biomass ratios much greater than 1 (e.g. Fuhrman et al.
1989, Cho \& Azam 1990, Buck et al. 1996). Although bacterial biomass does not seem to exceed algal biomass on an annual basis (Harrison et al. 2001, Li \& Harrison 2001), it should be noted that Buck et al.'s (1996) survey in these waters was carried out in summer while ours was in autumn. We did not sample micro- or mesozooplankton communities, but the addition of recent estimates of the biomass of both groups in subtropical North Atlantic waters (Huskin et al. 2001, Quevedo et al. 2003) suggest that the biomass pyramid in this oligotrophic region (mean heterotrophic: autotrophic ratio of $1.11 \pm 0.13$ ) may be less inverted than the average open-ocean estimate of 1.85 (Gasol et al. 1997).

Primary productivity displayed typically low values (Frazel \& Berberian 1990, Jochem \& Zeitzschel 1993, Morel et al. 1996, Marañón et al. 2000, 2001, Teira et al. 2003). Despite their much lower abundance, the variability in total PPP was largely caused by the presence of large cells. The contribution of $>2 \mu \mathrm{m}$ cells to primary production was significantly higher than its biomass contribution ( $t$-test for dependent samples, $\mathrm{p}<0.0001, \mathrm{n}=7$ ) confirming previous reports (Marañón et al. 2001) and providing further evidence of the different assimilation numbers of algae $<2 \mu \mathrm{m}$ and $>2 \mu \mathrm{m}$ in oligotrophic waters (Fernández et al. 2003), with mean integrated values of $0.53 \pm 0.06$, and $1.31 \pm$ $0.12 \mathrm{mgC} \mathrm{mg} \mathrm{chl} \mathrm{a}^{-1} \mathrm{~h}^{-1}$, respectively. Our estimates for the tropical (NATR) and the subtropical (NAST-E) regions compared reasonably well with the average primary production for October-November in the seasonal cycle proposed by Longhurst (1998): $\sim 300$ and $\sim 170 \mathrm{mg} \mathrm{C} \mathrm{m}^{-2} \mathrm{~d}^{-1}$. Although total values were similar (Table 1), slight differences in the fate of primary pro-

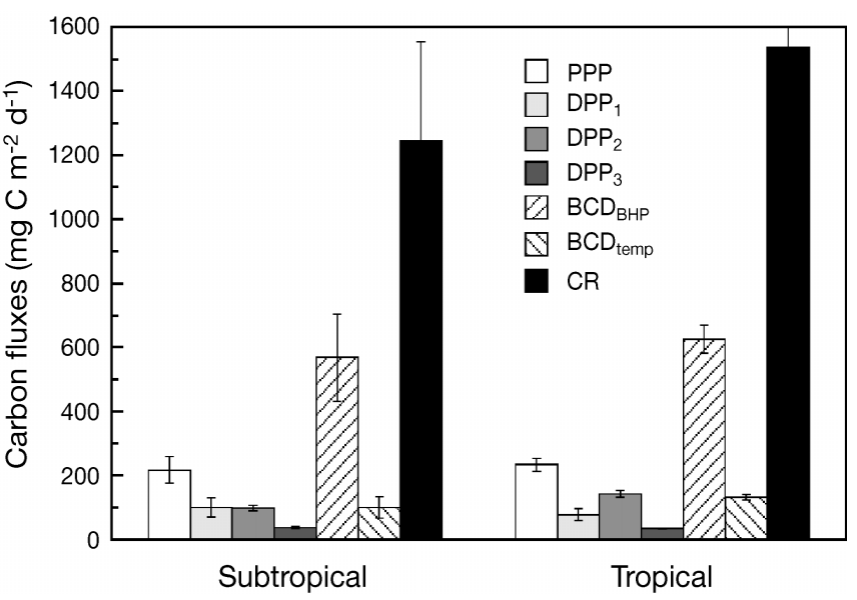

Fig. 9. Comparison between mean \pm SE rates of particulate (PPP) and dissolved $\left(\mathrm{DPP}_{1-3}\right)$ primary production, bacterial carbon demand $\left(\mathrm{BCD}_{\mathrm{BHP}}, \mathrm{BCD}_{\text {temp }}\right)$ and total community respiration $(\mathrm{CR})$ in subtropical and tropical domains. (See 'Discussion' for details) 
duction could be expected in the 2 regions. The contribution of $>20 \mu \mathrm{m}$ algae to total primary production and biomass was higher in the tropical domain, which could represent a relatively higher potential for particulate organic carbon export to deeper layers in tropical waters (Legendre \& Le Fèvre 1991, Kiørboe 1993).

In accordance with ${ }^{14} \mathrm{C}$ primary production measurements, gross primary production was low and comparable to previous data (Duarte et al. 2001, Serret et al. 2001) in the same area. GPP values higher than ours were measured in the Azores region under the influence of mesoscale structures that induced fertilization (González et al. 2001), and also closer to the African coast (González et al. 2002). GPP was significantly correlated with independent measurements of PPP rates, but assuming a photosynthetic quotient of 1 , it was considerably higher than PPP (linear regression GPP = $1.4+3.2 \mathrm{PP} ; \mathrm{r}=0.67, \mathrm{p}<0.001, \mathrm{n}=24$ ), reinforcing the hypothesis that the measurement of PPP by the ${ }^{14} \mathrm{C}$ technique yields estimates closer to net rather than to gross primary production (Marra 2002). Another important consideration is that whilst GPP includes dissolved primary production, which may reach relatively high values in oligotrophic environments (Teira et al. 2001, Morán et al. 2002a), the dissolved organic carbon (DOC) fraction was not measured in our ${ }^{14} \mathrm{C}$-uptake experiments.

As previously reported (Serret et al. 2001, Arístegui \& Harrison 2002), variability in integrated GPP was much higher than in CR (6- versus 2-fold). Given that bacterial biomass was clearly less than that of autotrophs in the photic layer, a balanced or even net autotrophic balance would have been expected according to trophic distribution models (Gasol et al. 1997). However, NCP was markedly negative at all but 1 station. Duarte et al. (2001) and Serret et al. (2001) predicted net heterotrophy in the oligotrophic Atlantic whenever GPP was lower than 94 to $100 \mathrm{mmolO}_{2} \mathrm{~m}^{-2}$ $\mathrm{d}^{-1}$ (1100 to $1200 \mathrm{mg} \mathrm{C} \mathrm{m}^{-2} \mathrm{~d}^{-1}$ ). All our measurements were below this value but we observed a positive NCP value at Stn 4 (Fig. 7B). This station was characterized by a thermohaline structure somewhat different from the rest (Fig. 2), and presented a shallow phytoplankton distribution (Fig. 3) and the highest chl a concentration (photic layer average $=0.36 \mathrm{mg} \mathrm{m}^{-3}$ ). Positive $\mathrm{NCP}$ at this station and a great variability in NCP over the relatively small range in the percentage of primary production due to the $<2 \mu \mathrm{m}$ cells found in our samples ( $41 \pm 3 \%$ SE) made the model by Serret et al. (2001) not applicable to our dataset.

The abundance of heterotrophic bacteria was maximum in surface waters (Fig. 6A), as reported by Zubkov et al. $(1998,2000 b)$, although we measured slightly higher values than those authors. Bacterial production rates were also similar to those reported by Zubkov et al. (2000b) in September and October, but about half the values obtained by González et al. (2001) and Teira et al. (2003) in April and August, respectively, in the Azores region. Differences in both sampling times and the substrate to carbon conversion factors used might be largely responsible for the discrepancy. The very small percentage of bacterial or 'bacterial production' to primary production $(7 \pm 1 \%)$, in accordance with the values reported by Hoppe et al. (2002) and Teira et al. (2003), supports the view that the widely accepted value of $30 \%$ (Cole et al. 1988) is not representative of open-ocean waters (Ducklow 1999, Anderson \& Ducklow 2001). The abundance of HDNA bacteria was slightly more correlated to bacterial production than LDNA abundance ( $\mathrm{r}=0.52$ vs $0.45, \mathrm{p}<0.01, \mathrm{n}=45)$, as previously reported for other systems (Zubkov et al. 2001, Morán et al. 2002b, Servais et al 2003), suggesting a higher activity of cells with higher DNA content (Gasol et al. 1999, Lebaron et al. 2001). These 2 subpopulations displayed different patterns of variation with depth. Both BHP (Fig. 6B) and the percentage of HDNA bacteria generally peaked in surface waters coincident with the depths of primary production maxima, suggesting a possible coupling between the activities of both planktonic groups. Indeed, although the correlation was not significant for integrated values, BHP and total PPP were correlated when all volumetric data were considered $(\mathrm{r}=0.57, \mathrm{p}<0.001, \mathrm{n}=35$, Fig. 8A).

We have recently (Morán et al. 2002a) proposed a more precise definition of phytoplankton-bacterioplankton coupling, taking into account bacterial carbon demand (BCD) and dissolved primary production (DPP) - the fraction amenable to concurrent and direct bacterial uptake. We have attempted an estimation of DPP based on different empirical models, relating it to either the percentage of particulate primary production $<2 \mu \mathrm{m}\left(\mathrm{DPP}_{1}\right)$, net community production $\left(\mathrm{DPP}_{2}\right)$ (Teira et al. 2001), or total particulate primary production $\left(\mathrm{DPP}_{3}\right)$ (Morán et al. 2002a). The contribution of grazers to DPP measurements in both studies was not specifically determined. $\mathrm{DPP}_{2}$ was calculated only for integrated data; $\mathrm{DPP}_{3}$ was correlated to $\mathrm{BHP}$ and $\mathrm{BCD}$ $(\mathrm{r}=0.59$ to $0.62, \mathrm{p}<0.001, \mathrm{n}=35$; Fig. 8B). Despite the different assumptions of the methods, the resulting values of PER (percent extracellular release) obtained with the 3 methods for the 2 domains ranged from 13 to $38 \%$, reasonable values for Atlantic oligotrophic areas according to experimental (Teira et al. 2001) and model (Fasham et al. 1999) results. As can be seen in Fig. 9, only for the highest DPP estimate $\left(\mathrm{DPP}_{2}\right)$ and if the 'true' $\mathrm{BCD}$ were $\mathrm{BCD}_{\text {temp }}$ rather than $\mathrm{BCD}_{\mathrm{BHP}}$ or a value between, could bacterial carbon demand be met by the concurrent production of DOC. Simultaneous determinations of BGE and DPP are clearly needed in 
order to conclude whether bacteria and phytoplankton are coupled in this open-ocean region (Morán et al. 2002a), but it seems from our calculations that a variable but significant amount of the substrate needed by bacteria was not provided by DOC released by primary producers; this was also found by Teira et al. (2003).

The great discrepancy between total community respiration and bacterial carbon demand shown in Fig. 9 deserves further attention. Provided that bacteria account for most community respiration in openocean waters (Williams 1981, Rivkin \& Legendre 2001) our estimates that at least $\sim 60 \%$ of CR was from other groups seem difficult to accept. This striking result may be related to the recognized problem of using different methodologies for estimating carbon fluxes (e.g. Geider 1997, del Giorgio \& Duarte 2002). Since our estimates of primary and bacterial production and community metabolism were similar to those by other researchers in the same area, it is possible that the $\mathrm{O}_{2}$-method overestimated $\mathrm{CR}$ and/or the ${ }^{3} \mathrm{H}$-leucine method underestimated bacterial production. Related to this, conspicuous loss of biomass of phytoplankton populations from oligotrophic areas after only $2 \mathrm{~h}$ incubation (Fernández et al. 2003) could seriously bias estimates during long incubations such as those required in $\mathrm{O}_{2}$ production-consumption experiments.

A higher demand for carbon by bacteria than that provided by concurrent primary production brings us back to the question of the general occurrence of net heterotrophy in the NE Atlantic (Agustí et al. 2001, Duarte et al. 2001, González et al. 2001, 2002, Serret et al. 2001). We have here provided consistent evidence of $\mathrm{O}_{2}$ respiration exceeding production that expands the data set presently available for the North Atlantic subtropical gyre, mostly for the NAST province. A recent hypothesis to explain the repeated observation of excess of consumption over production in the open sea is that short sampling periods probably miss episodic bursts of net autotrophy (Karl et al. 2003). Yet another question of interest in the ongoing debate on the metabolic balance of oligotrophic waters is: Would our results have been different had we sampled further west, towards the centre of the gyre? Some of the measurements of planktonic standing stocks and activity presented here were clearly lower than those obtained in waters closer to the African upwelling system (e.g. Agustí et al. 2001). NCP values that were positive or close to zero were reported by Serret et al. (2002) for the middle of the South Atlantic gyre, away from possible continental inputs of dissolved organic matter. Future research in the centre of the North Atlantic subtropical gyre will probably provide an answer to this question.
Acknowledgements. We are grateful to P. Estévez for her help with sampling and chlorophyll a measurements. This work was supported by the MCYT project CIRCANA (MAR19991072-C03-01) and the special action REN2001-3973-E.

\section{LITERATURE CITED}

Agustí S, Duarte CM, Vaqué D, Hein M, Gasol JM, Vidal M (2001) Food-web structure and elemental (C, N and P) fluxes in the eastern tropical North Atlantic. Deep-Sea Res II 48:2295-2321

Aiken J, Bale AJ (2000) An introduction to the Atlantic Meridional Transect (AMT) programme. Prog Oceanogr 45: $251-256$

Anderson TR, Ducklow HW (2001) Microbial loop carbon cycling in ocean environments studied using a simple steady-state model. Aquat Microb Ecol 26:37-49

Arístegui J, Harrison WG (2002) Decoupling of primary production and community respiration in the ocean: implications for regional carbon studies. Aquat Microb Ecol 29: 199-209

Buck KR, Chavez FP, Campbell L (1996) Basin-wide distributions of living carbon components and the inverted trophic pyramid of the central gyre of the North Atlantic Ocean, Summer 1993. Aquat Microb Ecol 10:283-298

Campbell L, Liu H, Nolla HA, Vaulot D (1997) Annual variability of phytoplankton and bacteria in the subtropical North Pacific Ocean at station ALOHA during the 1991-1994 ENSO event. Deep-Sea Res I 44:167-192

Cho BC, Azam F (1990) Biogeochemical significance of bacterial biomass in the ocean's euphotic zone. Mar Ecol Prog Ser 63:253-259

Cole JJ, Findlay S, Pace ML (1988) Bacterial production in fresh and saltwater ecosystems: a cross-system overview. Mar Ecol Prog Ser 43:1-10

del Giorgio PA, Cole JJ (1998) Bacterial growth efficiency in natural aquatic systems. Annu Rev Ecol Syst 29:503-541

del Giorgio PA, Cole JJ (2000) Bacterial growth efficiency and energetics. Chapter 10. In: Kirchman DL (ed) Microbial ecology of the Oceans. Plenum Press, New York, p 289-325

del Giorgio PA, Duarte CM (2002) Respiration in the open ocean. Nature 420:379-384

Duarte CM, Agustí S, Arístegui J, González N, Anadón R (2001) Evidence for a heterotrophic subtropical northeast Atlantic. Limnol Oceanogr 46:425-428

Ducklow HW (1992) Factors regulating bottom-up control of bacteria biomass in open ocean plankton communities. Ergeb Limnol 37:207-217

Ducklow HW (1999) The bacterial component of the oceanic euphotic zone. FEMS Microbiol Ecol 30:1-10

Fasham MJR, Boyd PW, Savidge G (1999) Modeling the relative contributions of autotrophs and heterotrophs to carbon flow at a Lagrangian JGOFS station in the Northeast Atlantic: the importance of DOC. Limnol Oceanogr 44: 80-94

Fernández E, Pingree RD (1996) Coupling between physical and biological fields in the North Atlantic subtropical front southeast of the Azores. Deep-Sea Res I 43: 1369-1393

Fernández E, Marañón E, Morán XAG, Serret P (2003) Potential causes for the unequal contribution of picophytoplankton to total biomass and productivity in oligotrophic waters. Mar Ecol Prog Ser 254:101-109

Frazel D W, Berberian G (1990) Distributions of chlorophyll and primary productivity in relation to water column 
structure in the eastern North Atlantic Ocean. Global Biogeochem Cycles 4:241-251

Fuhrman JA, Sleeter TD, Carlson CA, Proctor LM (1989) Dominance of bacterial biomass in the Sargasso Sea and its ecological implications. Mar Ecol Prog Ser 57:207-217

Garçon V, Oschlies A, Doney SC, McGillicuddy DJ, Waniek J (2001) The role of mesoscale variability on plankton dynamics in the North Atlantic. Deep-Sea Res I 48: $2199-2226$

Gasol JM, del Giorgio PA, Duarte CM (1997) Biomass distribution in marine planktonic communities. Limnol Oceanogr 42:1353-1363

Gasol JM, Zweifel UL, Peters F, Fuhrman JA, Hagström $\AA$ (1999) Significance of size and nucleic acid content heterogeneity as measured by flow cytometry in natural planktonic bacteria. Appl Environ Microbiol 65: 4475-4483

Geider RJ (1997) Photosynthesis or planktonic respiration? Nature 388:132

Gin KYH, Chisholm SW, Olson RJ (1999) Seasonal and depth variation in microbial size spectra at the Bermuda Atlantic time series station. Deep-Sea Res I 46:1221-1245

González N, Anadón R, Mouriño B, Fernández E, Sinha B, Escánez J, de Armas D (2001) The metabolic balance of the planktonic community in the North Atlantic Subtropical Gyre: the role of mesoscale instabilities. Limnol Oceanogr 46:946-952

González N, Anadón R, Marañón E (2002) Large-scale variability of planktonic net community metabolism in the Atlantic Ocean: importance of temporal changes in oligotrophic subtropical waters. Mar Ecol Prog Ser 233:21-30

Grasshoff K, Ehrhardt M, Kremling M (1983) Methods of seawater analysis, 2nd edn. Verlag Chemie, Weinheim

Harrison WG, Arístegui J, Head EJH, Li WKW, Longhurst AR, Sameoto DD (2001) Basin-scale variability in plankton biomass and community metabolism in the sub-tropical North Atlantic Ocean. Deep-Sea Res II 48:2241-2269

Hoppe HG, Gocke K, Koppe R, Begler C (2002) Bacterial growth and primary production along a north-south transect of the Atlantic Ocean. Nature 416:168-171

Huskin I, Anadón R, Medina G, Head RN, Harris RP (2001) Mesozooplankton distribution and copepod grazing in the subtropical Atlantic near the Azores: influence of mesoscale structures. J Plankton Res 23:671-691

Jochem FJ, Zeitzschel B (1993) Productivity regime and phytoplankton size structure in the tropical and subtropical North Atlantic in spring 1989. Deep-Sea Res II 40: 495-519

Karl DM, Laws EA, Morris P, Williams PJ LeB, Emerson S (2003) Metabolic balance of the open sea. Nature 246:32

Kiørboe T (1993) Turbulence, phytoplankton cell size and the structure of pelagic food webs. Adv Mar Biol 29:1-72

Kirchman DL, Ducklow HW (1993) Estimating conversion factors for the thymidine and leucine methods for measuring bacterial production. In: Kemp PF, Sherr BF, Sherr EB, Cole JJ (eds) Handboook of methods in aquatic microbial ecology. Lewis Publishers, Boca Raton, FL, p 513-517

Lebaron P, Servais P, Agogué H, Courties C, Joux F (2001) Does the high nucleic acid content of individual bacterial cells allow us to discriminate between active cells and inactive cells in aquatic systems? Appl Environ Microbiol 67:1775-1782

Lee S, Fuhrman JA (1987) Relationships between biovolume and biomass of naturally derived marine bacterioplankton. Appl Environ Microbiol 53:1298-1303

Legendre L, Le Fèvre J (1991) From individual plankton cells to pelagic marine ecosystems and to global biogeochemi- cal cycles. In: Demers S (ed) Particle analysis in oceanography. Springer-Verlag, Berlin, p 261-300

Li WKW (1995) Composition of ultraphytoplankton in the central North Atlantic. Mar Ecol Prog Ser 122:1-8

Li WKW (2002) Macroecological patterns of phytoplankton growth in the northwestern North Atlantic Ocean. Nature 419:154-157

Li WKW, Harrison WG (2001) Chlorophyll, bacteria and picophytoplankton in ecological provinces of the North Atlantic. Deep-Sea Res II 48:2271-2293

Li WKW, Dickie PM, Harrison WG, Irwin BD (1993) Biomass and production of bacteria and phytoplankton during the spring bloom in the western North Atlantic Ocean. Deep Sea Res II 40:307-327

Longhurst A (1998) Ecological geography of the sea. Academic Press, San Diego

Longhurst A, Sathyendranath S, Platt T, Caverhill C (1995) An estimate of global primary production in the ocean from satellite radiometer data. J Plankton Res 17:1245-1271

Marañón E, Holligan PM (1999) Photosynthetic parameters of phytoplankton from $50^{\circ} \mathrm{N}$ to $50^{\circ} \mathrm{S}$ in the Atlantic Ocean. Mar Ecol Prog Ser 176:191-203

Marañón E, Holligan PM, Varela M, Mouriño B, Bale AJ (2000) Basin-scale variability of phytoplankton biomass, production and growth in the Atlantic Ocean. Deep-Sea Res I 47:825-857

Marañón E, Holligan PM, Barciela R, González N, Mouriño B, Pazó MJ, Varela M (2001) Patterns of phytoplankton size structure and productivity in contrasting open ocean environments. Mar Ecol Prog Ser 216:43-56

Marañón E, Behrenfeld MJ, González N, Mouriño B, Zubkov MV (2003) High variability of primary production in oligotrophic waters of the Atlantic Ocean: uncoupling from phytoplankton biomass and size structure. Mar Ecol Prog Ser 257:1-11

Marra J (2002) Approaches to the measurement of plankton production. In: Williams PJ LeB, Thomas DN, Reynolds C (eds) Phytoplankton productivity: carbon assimilation in marine and freshwater ecosystems. Blackwell Science, Oxford, p 78-108

Morán XAG, Estrada M, Gasol JM, Pedrós-Alió C (2002a) Dissolved primary production and the strength of phytoplankton-bacterioplankton coupling in contrasting marine regions. Microb Ecol 44:217-223

Morán XAG, Gasol JM, Pedrós-Alió C, Estrada M (2002b) Partitioning of phytoplanktonic organic carbon production and bacterial production along a coastal-offshore gradient in the NE Atlantic during different hydrographic regimes. Aquat Microb Ecol 29:239-252

Morel A, Antoine D, Babin M, Dandonneau Y (1996) Measured and modeled primary production in the northeast Atlantic (EUMELI JGOFS program): the impact of natural variations in photosynthetic parameters and model predictive skill. Deep-Sea Res I 43:1273-1304

Mouriño B, Fernández E, Serret P, Harbour D, Sinha B, Pingree R (2001) Variability and seasonality of physical and biological fields at the Great Meteor Tablemount (subtropical NE Atlantic). Oceanol Acta 24:167-185

Oudot C, Gerard R, Morin P, Gningue I (1988) Precise shipboard determination of dissolved oxygen (Winkler procedure) for productivity studies with a commercial system. Limnol Oceanogr 33:146-150

Partensky F, Blanchot J, Lantoine F, Neveux J, Marie D (1996) Vertical structure of picophytoplankton at different trophic sites of the tropical northeastern Atlantic Ocean. Deep-Sea Res I 43:1191-1213

Partensky F, Blanchot J, Vaulot D (1999) Differential distribu- 
tion and ecology of Prochlorococcus spp. and Synechococcus spp. in oceanic waters: a review. Bull Inst Océanogr 19:457-475

Pingree RD (1997) The eastern subtropical gyre (North Atlantic): flow rings recirculations structure and subduction. J Mar Biol Assoc UK 77:573-624

Pingree RD (2002) Ocean structure and climate (eastern North Atlantic): in situ measurement and remote sensing (altimeter). J Mar Biol Assoc UK 82:681-707

Platt T, Subba Rao DW, Irwin B (1983) Photosynthesis of picoplankton in the oligotrophic ocean. Nature 301:702-704

Pomeroy LR, Sheldon JE, Sheldon WM Jr (1994) Changes in bacterial numbers and leucine assimilation during estimations of microbial respiratory rates in seawater by the precision Winkler method. Appl Environ Microb 60:328-332

Quevedo M, Anadón R (2001) Protist control of phytoplankton growth in the subtropical north-east Atlantic. Mar Ecol Prog Ser 221:29-38

Quevedo M, Viesca L, Anadón R, Fernández E (2003) The protistan microzooplankton community in the oligotrophic north-eastern Atlantic: large- and mesoscale patterns. J Plankton Res 25:551-563

Rivkin RB, Legendre L (2001) Biogenic carbon cycling in the upper ocean: effects of microbial respiration. Science 291: $2398-2400$

Serret P, Robinson C, Fernández E, Teira E, Tilstone G (2001) Latitudinal variation of the balance between plankton photosynthesis and respiration in the eastern Atlantic Ocean. Limnol Oceanogr 46:1642-1652

Serret P, Fernández E, Robinson C (2002) Biogeographic differences in the net ecosystem metabolism of the open ocean. Ecology 83:3225-3234

Servais P, Casamayor EO, Courties C, Catala P, Parthuisot N,

Editorial responsibility: Otto Kinne (Editor),

Oldendorf/Luhe, Germany
Lebaron P (2003) Activity and diversity of bacterial cells with high and low nucleic acid content. Aquat Microb Ecol 33:41-51

Smith DC, Azam F (1992) A simple, economical method for measuring bacterial protein synthesis rates in seawater using ${ }^{3} \mathrm{H}$-leucine. Mar Microb Food Webs 6:107-114

Straskraba M, Gnauck AH (1985) Freshwater ecosystems: modelling and simulation. Elsevier, Amsterdam

Teira E, Pazó MJ, Serret P, Fernández E (2001) Dissolved organic carbon production by microbial populations in the Atlantic Ocean. Limnol Oceanogr 46:1370-1377

Teira E, Pazó MJ, Quevedo M, Fuentes MV, Niell FX, Fernández E (2003) Rates of dissolved organic carbon production and bacterial activity in the eastern North Atlantic Subtropical Gyre during summer. Mar Ecol Prog Ser 249: 53-67

Williams PJ LeB (1981) Microbial contribution to overall marine plankton metabolism: direct measurements of respiration. Oceanol Acta 4:359-364

Zubkov MV, Sleigh MA, Tarran GA, Burkill PH, Leakey RJG (1998) Picoplanktonic community structure on an Atlantic transect from $50^{\circ} \mathrm{N}$ to $50^{\circ} \mathrm{S}$. Deep-Sea Res I 45:1339-1355

Zubkov MV, Sleigh MA, Burkill PH, Leakey RJG (2000a) Picoplankton community structure on the Atlantic Meridional Transect: a comparison between seasons. Prog Oceanogr 45:369-386

Zubkov MV, Sleigh MA, Burkill PH, Leakey RJG (2000b) Bacterial growth and grazing loss in contrasting areas of North and South Atlantic. J Plankton Res 22:685-711

Zubkov MV, Fuchs BM, Burkill PH, Amann R (2001) Comparison of cellular and biomass specific activities of dominant bacterioplankton groups in stratified waters of the Celtic Sea. Appl Environ Microbiol 67:5210-5218

Submitted: August 21, 2003; Accepted: February 17, 2004 Proofs received from author(s): June 4, 2004 